\title{
Efektivitas Biro Umum dalam Menjalankan Program E-Surat di Sekretariat Daerah Provinsi Kalimantan Barat
}

\author{
Rizky Permata Sari ${ }^{1}$ \\ ${ }^{1}$ Pemkot Kota Pontianak \\ Korespondesi Penulis Utama : qpermataberau@gmail.com
}

\begin{abstract}
The purpose of this research was to find out and analyze the effectiveness of the bureau of general affairs in running the Electronic Letter program at The Regional Secretariat of West Kalimantan Province. This Study uses Gibson et al's theory of short-term Effectiveness which is seen from production, effieciency, and satisfaction. The method used in this research is qualitative, with descriptive research. The results showed that the effectiveness of bureau of general affairs in running the Electronic Letter program at The Regional Secretariat of West Kalimantan Province already existed but was not optimal. The effectiveness of the bureau of general affairs in running the Electronic Letter program has not been effective, due to, namely a) production; which consists of incoming letter service, mail disposition information services, letter numbering service have been running according to the stages even more efficient when viewed from the previous system, but not yet optimal. This is evidenced by the internet network that is still experience problems, employees or admins who are still experiening human error, and limited facilities and infrastructure; b) effieciency; which consists of time efficiency, service cost efficiency and service procedure effieciency, in terms of efficiency both internal and external parties state that it is quite optimal because the service is faster and more efficient but still needs to be improved; c) satisfaction; internal parties feel they are quite satisfied even though they are not optimal because there are still problems in the production section, but external parties are not satisfied this is because there are parties who are still having trouble tracking the whereabouts of the letter. The recommendations of this research are: 1) changing the mindset of employees gradually by increasing socialization related to the Electronic Letter program and increasing the motivation of each employee by building good relations between employees within the The Regional Secretariat of West Kalimantan Province; 2) involving all OPD (regional device organizations) to use the Electronic Letter application; 3) the provision of good facilities and infrastructure.

Keywords: Effectiveness, The Electronic Letter Program, Bureau of General Affairs
\end{abstract}

\begin{abstract}
ABSTRAK
Tujuan penelitian ini adalah ingin mengetahui dan menganalisis efektivitas Biro Umum dalam menjalankan program E-surat di Sekretariat Daerah Provinsi Kalimantan Barat.Penelitian ini menggunakan teori Gibson dl tentang Efektivitas Jangka Pendek yaitu dilihat dari Produksi, Efisiensi, dan Kepuasan.Metode yang digunakan dalam penelitian ini adalah kualitatif, dengan penelitian deskriptif. Hasil penelitian menunjukkan bahwa efektivitas Biro Umum dalam menjalankan program E-surat di Sekretariat Daerah Provinsi Kalimantan Barat sudah ada namun belum optimal. Efektivitas biro umum dalam menjalankan program E-surat belum berjalan efektif, disebabkan oleh, yaitu a) produksi; yang terdiri pelayanan surat masuk, pelayanan informasi disposisi surat, pelayanan penomoran surat sudah berjalan sesuai dengan tahapan bahkan lebih efisien jika dilihat dari sistem sebelumnya, namun belum optimal. Hal ini dibuktikan dengan
\end{abstract}




\section{JPASDEV}

Journal of Public Administration

and Sociology of Development

Vol. 2, No. 2, Desember 2021

jaringan internet yang masih mengalami gangguan, pegawai atau admin yang masih mengalami human error, serta sarana dan prasarana yang masih terbatas; b) efisiensi; yang terdiri dari efisiensi waktu, efisiensi biaya pelayanan dan efisiensi prosedur pelayanan, dalam hal efisiensi baik pihak internal maupun eksternal menyatakan sudah cukup optimal karena pelayanan lebih cepat dan efisien namun tetap harus ditingkatkan; c) kepuasan; pihak internal merasakan sudah cukup puas walaupun belum optimal karena masih terdapat kendala dibagian produksi, namun pihak eksternal merasa belum puas hal ini dikarenakan adanya pihak yang masih kesulitan dalam melacak keberadaan suratnya. Rekomendasi penelitian ini adalah: 1) mengubah pola pikir pegawai secara bertahap dengan meningkatkan sosialisasi terkait program E-surat serta meningkatkan motivasi tiap pegawai dengan cara membangun hubungan baik antar pegawai di lingkup Sekretariat Daerah Provinsi Kalimantan Barat; 2) melibatkan seluruh OPD (organisasi perangkat daerah) untuk menggunakan aplikasi E-surat; 3) disediakannya sarana dan prasarana yang baik.

Kata Kunci: Efektivitas, Program E-surat, Biro Umum 


\section{JPASDEV}

Journal of Public Administration

and Sociology of Development

Vol. 2, No. 2, Desember 2021

\section{PENDAHULUAN}

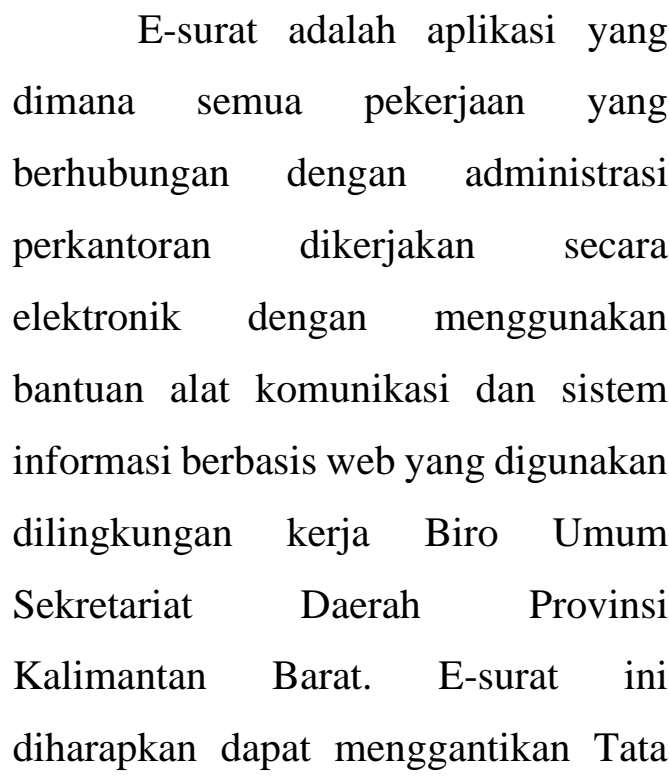

Naskah Dinas yang dikelola secara

manual menjadi elektronik. Peralihan

government diperlukan adanya kebijakan dan strategi. Kebijakan dan strategi tersebut diatur dalam Instruksi Presiden No. 3 Tahun 2003 tentang Kebijakan dan Strategi Nasional Pengembangan E-government di seluruh jajaran pemerintahan secara menyeluruh. Dalam kebijakan ini diharapkan terbentuknya pemerintahan yang bersih, transparan, dan mampu menjawab tuntutan perubahan secara efektif.

Sedangkan untuk Tata Naskah Dinas secara Elektronik diatur dalam
Tata Naskah Dinas Manual menjadi Tata Naskah Dinas Elektronik ini diharapkan dapat meningkatkan kecepatan pelayanan pemerintah elektronik, dalam hal ini E-government. E-government merupakan suatu sistem teknologi yang dikembangkan oleh pemerintah untuk meningkatkan pelayanan publik dengan memberikan pilihan kepada masyarakat untuk mendapatkan kemudahan akses informasi publik.

Dalam pengembangan $E$ -

Peraturan Menteri Pendayagunaan Aparatur Negara dan Reformasi Birokrasi (Menpan RB) No. 6 Tahun 2011 tentang Pedoman Umum Tata Naskah Dinas Elektronik (TNDE).

Untuk meningkatkan efektivitas dan efisiensi penyelenggaraan pemerintah, serta terciptanya koordinasi, integrasi sinkronisasi, dan simplikasi antar instansi pemerintah provinsi Kalimantan barat serta memberi kemudahan dalam pengelolaan dokumen naskah dinas maka pada awal tahun 2020 , 


\section{JPASDEV}

Journal of Public Administration

and Sociology of Development

Vol. 2, No. 2, Desember 2021

Biro Umum menggunakan program Esurat untuk mewujudkan hal tersebut.

Selama kurang lebih berjalan 1 (satu) tahun pelaksanaan program E-surat di Biro Umum Sekretariat Daerah, jaringan internet menjadi salah satu kendala pelaksanaan proses program ESurat. Hal ini dikarenakan segala bentuk urusan pemerintahan di tingkat Pemerintah Provinsi Kalimantan Barat di bidang komunikasi, informatika, persandian dan statistik bersumber dari jaringan internet yang terdapat pada Dinas Komunikasi dan Informatika (Diskominfo) Provinsi Kalimantan Barat. Dengan kata lain Diskominfo Provinsi Kalimantan Barat menjadi penyedia jaringan internet dilingkup Pemerintahan Provinsi Kalimantan Barat. Pada bulanan Barat selama bertahun- tahun telah terbiasa menggunakan sistem Tata Naskah Dinas Manual sehingga terdapat tantangan untuk merubah pola pikir tersebut.SDM atau pegawai di Biro Umum Sekretariat Daerah Provinsi Kalimantan Barat yaitu belum semua pegawai menguasai tentang cara bulan tertentu pada saat instansi lain sedang menggunakan jaringan internet maka akan mempengaruhi proses kerja instansi lain termasuk Biro Umum Sekretariat Daerah.Selain jaringan internet keterbatasan peralatan pendukung seperti komputer juga menjadi kendala proses pelaksanaan program E-surat, dibeberapa bidang masih terdapat jenis komputer yang memiliki spesifikasi masih rendah belum mengalami perubahan. Hal ini terkadang menghambat proses kerja program Esurat.

Selain itu hal yang menjadi pokok permasalahan adalah dari segi Sumber Daya Manusia (SDM).SDM atau pegawai di Kantor Biro Umum Sekretariat Daerah Provinsi Kalimant

penggunaan aplikasi E-Surat, hal ini dapat dipengaruhi oleh beberapa faktor diantaranya adalah usia dan tingkat pendidikannya.

Beranjak dari permasalahan diatas, penelitian ini difokuskan pada efektivitas jangka pendek Biro Umum dalam menjalankan program E-surat di 


\section{JPASDEV}

Journal of Public Administration

and Sociology of Development

Vol. 2, No. 2, Desember 2021

Sekretariat Daerah Provinsi Kalimantan Barat yang dimana kaitannya terhadap peningkatan kinerja Biro Umum dalam menjalankan sistem pemerintahan khususnya pada bidang surat menyurat. Dari uraian di atas, peneliti merumuskan tujuan dari penelitian untuk mengetahui dan menganalisis efektivitas biro umum dalam menjalankan program E-surat di sekretariat daerah provinsi Kalimantan barat.

\section{METODE PENELITIAN}

Penelitian ini menggunakan penelitian kualitatif dengan metode deskriptif dengan pendekatan induktif untuk menggambarkan sedalamdalamnya efektivitas biro umum dalam menjalankan program E-surat di sekretariat daerah provinsi Kalimantan barat.

Noor, Juliansyah menyatakan pendekatan kualitatif adalah suatu proses penelitian dan pemahaman yang berdasarkan pada metodologi yang menyelidiki suatu fenomena sosial dan masalah manusia. Pada pendekatan ini, peneliti menekankan sifat realitas yang terbangun secara sosial, hubungan erat antara peneliti dan subjek yang diteliti.

Dalam penelitian ini penulis menggunakan pendekatan deskriptif yang berkaitan dengan penggambaran suatu situasi atau gejala tertentu secara terperinci.Menurut Noor penelitian deskriptif adalah penelitian yang berusaha mendeskripsikan suatu gejala, peristiwa, kejadian yang terjadi saat sekarang.

Dalam penelitian ini penulis menggunakan pendekatan induktif, yaitu berpijak pada hal- hal yang bersifat khusus (fakta), kemudian mengambil kesimpulan umum apakah sesuai dengan dalil, hukum, dan teori yang ada.Pendekatan induktif dimulai dari fakta di lapangan, dianalisis, dibuat pertanyaan kemudian dihubungkan dengan teori, dalil, hukum yang sesuai kemudian pernyataan hingga kesimpulan.

Penetapan lokasi penelitian sangat penting dalam rangka mempertanggungjawabkan data yang diperoleh.Untuk itu peneliti memilih 


\section{JPASDEV}

Journal of Public Administration

and Sociology of Development

Vol. 2, No. 2, Desember 2021

lokasi di Kantor Biro Umum Sekretariat Daerah Provinsi Kalimantan Barat.

Pada penelitian ini peneliti menggunakan teknik purposive atau pengambilan informan secara sengaja/ bertujuan atau atas pertimbangan tertentu. Dalam penelitian ini sumber data yang dipergunakan meliputi: 1) Data primer, yaitu data yang diperoleh langsung dari informan atau dari sumbernya berupa wawancara, sekaligus sebagai subjek penelitian; 2) Data sekunder, yaitu data yang diperoleh dengan cara menyalin atau mengutip catatan- catatan atau dokumen yang ada, sekaligus sebagai objek dari penelitian ini.

\section{HASIL DAN PEMBAHASAN}

Berkenaan dengan efektivitas biro

umum dalam menjalankan program Esurat di sekretariat daerah provinsi Kalimantan barat, maka dalam penelitian ini digunakan efektivitas jangka pendek menurut Gibson yang dimana meliputi: produksi (production), efisiensi (efficiency), dan kepuasan (satisfaction). Teori ini digunakan peneliti untuk mengetahui bagaimana efektivitas Biro Umum dalam menjalankan Program Esurat di Sekretariat Daerah Provinsi Kalimantan Barat. Penjelasannya sebagai berikut:

\section{Produksi}

Produksi merupakan salah satu acuan untuk melihat sejauhmana pembentukan sebuah organisasi, dapat meningkatkan produk yang dihasilkan baik berupa barang maupun jasa.Dalam hal ini salah satu produk dari Biro Umum ialah program E-surat tersebut.Produksi berhubungan dengan sejauhmana pelayanan yang diselenggarakan oleh Biro Umum Sekretariat Daerah Provinsi Kalimantan Barat dapat meningkatkan kinerja organisasi berserta para pegawainya serta tujuan pelayanan kepada pimpinan dan masyarakat bisa terlaksana. Produksi tersebut terdiri dari: a) Pelayanan Surat Masuk; b) Pelayanan Informasi Disposisi Surat; c) Pelayanan Penomoran Surat. 


\section{JPASDEV}

Journal of Public Administration

and Sociology of Development

Vol. 2, No. 2, Desember 2021

Dalam program E-surat ini untuk melihat seberapa efektifnya dapat dilihat dari lebih terstruktur dan terdeteksi dengan baik keberadaan surat berserta disposisi tiap masing- masing surat yang ada. Berdasarkan hasil wawancara yang telah dilakukan penulis bersama beberapa informan, peneliti dapat menyimpulkan bahwa efektivitas program E-surat pada Biro Umum Sekretariat Daerah Provinsi Kalimantan Barat dalam Produk Pelayanan Surat Masuk dan Produk Pelayana Informasi Disposisi Surat sudah lebih efektif daripada sebelumnya walaupun belum optimal. Hal ini disebabkan karena beberapa alasan, diantaranya yaitu keluhan surat hilangatau tercecer sudah berkurang, karena setiap surat masuk beserta disposisinya telah tersimpan di sebuah aplikasi yaitu E-surat tersebut.

Untuk produk pelayanan penomoran surat dalam program E-surat juga memiliki pengaruh yaitu pada saat menggunakan aplikasi E-surat untuk mengecek keberadaan surat yang dicari, membutuhkan nomor surat tersebut, sehingganya pada saat pelayanan penomoran surat harus benar- benar sesuai dengan ketentuan yang ada.

\section{Efisiensi}

Efisiensi merupakan suatu ukuran keberhasilan yang dinilai dari segi besarnya sumber/biaya untuk mencapai hasil dari kegiatan yang dijalankan. Efisiensi adalah perbandingan yang terbaik antara input (masukan) dan output (hasil antara keuntungan dengan sumbersumber yang dipergunakan) seperti halnya juga hasil optimal yang dicapai dengan penggunaan sumber yang terbatas.

Dalam kontek melihat efisiensi program E-surat di Biro Umum Sekretariat Daerah Provinsi Kalimantan Barat, maka akan dinilai sejauhmana program tersebut dapat mencapai keberhasilan pelayanan yang cepat, efektif dan tidak memakan biaya yang besar. Adapun dalam melihat efisiensi program E-surat akan dikaji dari aspek efisiensi waktu, biaya dan prosedur, penjelasannya sebagai berikut: a) Efisiensi waktu, Salah satu tujuan program E-surat adalah untuk 


\section{JPASDEV}

Journal of Public Administration

and Sociology of Development

Vol. 2, No. 2, Desember 2021

mengefisienkan pelayana terhadap

Mengenai hasil penelitian terkait

pimpinan, meningkatkan efisiensi

efisiensi waktu pada program E-surat,

kepengurusan persuratan di lingkungan

penulis menyimpulkan bahwa program

Sekretariat Daerah Provinsi Kalimantan

E-surat sudah cukup efektif dalam

Barat. Sebelum adanya program E-surat

untuk mencari tahu keberadaan surat

(tracking surat) cukup memakan waktu

yang lama dikarenakan harus mencari

secara manual sedangkan jumlah surat

yang sangat banyak, selain itu status surat

yang dicari juga tidak pasti apakah sudah

masuk dalam pencatatan atau hilang.

Selain itu permasalahan lainnya adalah

disposisi dari surat tersebut. Tentunya

pihak yang mengirimkan surat ingin

mengetahui apakah surat yang

dikirimkan sudah sampai sesuai tujuan

atau belum serta apakah ada balasan dari

surat tersebut. Sehingganya pemilik surat

akan memakan waktu yang lama untuk

sekedar mencari satu buah surat. Namun

dengan program E-surat tersebut pemilik

surat tidak perlu kesana kemari untuk mencari suratnya, hanya dengan menggunakan aplikasi E-surat tersebut akan dilampirkan keberadaan (tracking) surat berserta dengan disposisinya.

mengefisienkan waktu namun belum maksimal. Hal tersebut diketahui berdasarkan hasil wawancara yang dilakukan penulis dengan beberapa informan. Dari hasil wawancara tersebut, hampir seluruh admin dari aplikasi Esurat di tiap- tiap unit mengatakan dalam mencari trackingsurat lebih cepat dibandingkan mencari dengan cara manual.

Dari hasil wawancara dengan Dwi Purwanto, A.Md selaku admin Program E-surat di TU Biro Umum yang mana merupakan tempat sumber awal Instansi atau organisasi memasukkan surat terkait hal- hal yang bersangkutan dengan Biro Umum Setda Provinsi Kalimantan Barat, ia mengatakan:

"dengan adanya aplikasi E-surat
ini pengelolaan surat menjadi
lebih rapid an teratur, selain itu
pencarian suatu surat tidak perlu
memakan waktu yang lama lagi
karena hanya dengan
menggunakan nomor surat di 


\section{JPASDEV}

Journal of Public Administration

and Sociology of Development

Vol. 2, No. 2, Desember 2021

input pada aplikasi E-surat tersebut, surat yang dicari bisa dengan mudah dilacak sampai mana keberadaannya dan apa isi disposisinya. Namun terdapat permasalahan misalnya saja jika ada staf atau petugas layanan yang lupa untuk mengentri surat yang masuk ke dalam sistem aplikasi maka surat tersebut tidak akan bisa dilacak". (wawancara pada tanggal 22 april 2021).

Berdasarkan hasil wawancara tersebut menunjukkan bahwa jika dibandingkan dengan sebelum adanya Program E-surat di Biro Umum Sekretariat Daerah Provinsi Kalimantan Barat, proses pengelolaan surat menjadi lebih efisien, dimana baik petugas layanan maupun pengguna layanan tidak perlu membuang waktu pergi ke bidang satu dan bidang lainnya untuk mengecek surat. Akan tetapi dari keterangan diatas, hal penting yang perlu diperhatikan bahwa surat yang ada bisa dilacak keberadaannya apabila telah dientri atau dimasukkan ke dalam aplikasi, jika hal tersebut terlupakan atau bahkan surat hilang dan tercecer maka hal ini menjadi permasalahan seperti pada saat masih menggunakan pencatatan secara manual.

Ketepatan waktu pelayanan memang akan brsinggungan dengan jumlah dan kompetensi pegawai dalam memproses berkas atau surat yang masuk, serta kesiapan sarana dan prasarana kerja untuk kelancaran para petugas dalam bekerja. Bisa dimaklumi manakala pelayanan tidak sesuai dengan semestinya, karena tidak terdapat pegawai dan fasilitas kerja yang memadai; b) Efisiensi biaya pelayanan,Salah satu aspek dalam menilai efisiensi pelayanan adalah melihat sejauhmana proses suatu program menggunakan biaya apakah telah sesuai dengan ketentuan yang telah ditetapkan. Program E-surat di Biro Umum Sekretariat Daerah Provinsi Kalimantan Barat adalah sebuah aplikasi yang berbasis web, dimana aplikasi ini merupakan hasil kerja sama antara Biro Umum dan Dinas Komunikasi dan Informatika (Diskominfo) Provinsi Kalimantan Barat. Program E-surat ini jika dilihat mulai dari segi pembiayaan pembuatan aplikasinya tidak 


\section{JPASDEV}

Journal of Public Administration

and Sociology of Development

Vol. 2, No. 2, Desember 2021

menggunakan biaya sama sekali, hanya sebatas kerja sama anatar Instansi pemerintah dalam mewujudkan pelayanan yang prima baik terhadap pimpinan maupun masyarakat. Selain itu dikarenakan program E-surat ini berbasis web maka jika ingin menggunakan aplikasi ini cukup menggunakan internet yang dimiliki masing- masing.

Sedangkan jika dilihat dari segi pelayanan, para staf atau petugas layanan yang bertugas mengoperasikan Program E-surat ini tidak menuntut biaya apapun terhadap tamu atau pengguna layanan.Hal ini dikarenakan sudah menjadi bagian dari tugas pokok dan fungsi tiap masing- masing pegawai untuk menjalankan tugasnya, hanya saja Program E-surat ini merupakan suatu solusi dalam memudahkan pegawai dalam melaksakan tugas pokok dan fungsinya.

Dengan kelebihan yang dimiliki Program E-surat baik dari pembuatan dan prosedur pelayanannya, maka biaya pelayanan akan menjadi lebih efisien. Karena Program E-surat sesuai dengan standar operasional prosedur (SOP) sehingga efisiensi biaya itu sudah terwujud.

Hal ini juga disampaikan oleh Ismep Hardinata, S.Pi, ME selaku Kepala Bagian Tata Usaha di Biro Umum Sekretariat Daerah Provinsi Kalimantan Barat, dalam wawancara ia mengatakan:

"benar, untuk Program E-surat ini pada awal mulanya adalah bentuk inovasi dari beberapa staf yang mencoba mencari solusi dari permasalahan yang dihadapi terkait pengelolaan surat yang sering hilang atau tercecer, dan mencoba untuk berkoordinasi dengan pihak Diskominfo ternyata dari pihak Diskominfo menyanggupi untuk membantu membuatkan aplikasi yang dimaksud, hal ini tidak menggunakan biaya apapun hanya sebatas kerja sama antar instansi dalam menjalankan tugas pokok dan fungsi masingmasing, walaupun Program Esurat ini jika dilihat dari segi landasan normatifnya belum ada, namun dengan berjalannya program dan dampak yang dirasakan saat ini, untuk landasan normatifnya sedang dalam proses pembuatan mengingat sangat 


\section{JPASDEV}

Journal of Public Administration

and Sociology of Development

Vol. 2, No. 2, Desember 2021

perlu untuk administrasi surat". (wawancara pada tanggal 22 april 2021).

Berdasarkan hasil wawancara tersebut, dapat di analisis bahwa Program E-surat di Biro Umum telah memberikan dampak positif terhadap efisiensi biaya pelayanan. Efisiensi biaya juga dirasakan oleh tamu atau pengguna layanan karena cukup datang di satu tempat tanpa pergi ke instansi lainnya yang dapat menimbulkan biaya diluar biaya pelayanan, bahkan jika perlu tamu bisa mengecek sendiri secara langsung melalui web, hanya saja masih banyak pihak luar yang tidak memahami tata cara pengecekan tracking surat secara sendiri, lebih memilih untuk datang langsung ke TU Biro Umum untuk menanyakan; c) Efisiensi prosedur pelayanan,Prosedur dalam proses pelayanan Program E-surat adalah berkenaan dengan alur pelayanan yang harus dilalui oleh pengguna layanan mulai dari memasukkan surat hingga hasil disposisi dari surat tersebut. Mekanisme pelayanan yang baik akan memudahkan masyarakat/ publik yang akan berurusan tidak mengalami kesulitan dan mudah mengerti dengan alur pelayanan serta pesyaratanpersyaratan yang harus dipenuhi.

Adapun mekanisme pemrosesan Program E-surat di Biro Umum Sekretariat Daerah Provinsi Kalimantan Barat adalah sebagai berikut: 1) Pengguna layanan atau tamu baik dari Instansi atau organisasi lain mengantarkan surat ke biro umum; 2) Surat di entri atau dimasukkan ke sistem oleh admin biro umum; 3) Surat yang telah di entri kemudian di scan; 4) Setelah di scan tambahan keterangan surat, lalu input keterangan tersebut ke dalam sistem; 5) Setelah itu surat akan diteruskan sesuai dengan ketentuan yang berlaku biasanya dari TU Biro Umum, diteruskan kepada TU Asisten, lalu diteruskan kepada TU Sekda, dan terakhir diteruskan kepada TU Wakil Gubernur atau TU Gubernur, tergantung sifat surat ditujukan untuk siapa; 6) Setelah surat diteruskan maka akan diinput ke sistem beserta dengan isi disposisi terhadap surat tersebut; 7) Pihak pengguna layanan kapan saja bisa mengecek tracking dari surat yang dimilikinya hanya dengan 


\section{JPASDEV}

Journal of Public Administration

and Sociology of Development

mengakses web yang disediakan atau menanyakan langsung kebagian TU Biro Umum, atau juga bisa melalui via telepon pada nomor telepon yang disediakan; 8) Jika pengguna layanan ingin mencari surat yang diinginkan yang dilakukan adalah menginput ke dalam sistem berdasarkan suatu parameter diantaranya yaitu: a) cari berdasarkan tahun, b) cari berdasarkan asal surat, c) cari berdasarkan tujuan surat, d) cari berdasarkan tanggal surat, e) cari berdasarkan nomor surat, f) cari berdasarkan perihal surat, g) cari berdasarkan jenis surat.

\section{Mengenai efisiensi terhadap} prosedur dan mekanisme pelayanan, dari hasil wawancara yang penulis lakukan dengan Mohammad Bari, S.Sos, M.Si selaku Kepala Biro Umum Sekretariat Daerah Provinsi Kalimantan Barat, ia menyatakan bahwa:

"mengenai efisiensi prosedur pelayanan Program E-surat di Biro Umum Sekretariat Daerah Provinsi Kalimantan Barat saya rasa sudah sangat efisien jika dibandingkan dengan prosedur pelayanan pengurusan surat pada

Vol. 2, No. 2, Desember 2021 saat pencatatan manual sebelumnya. Kalau sekarang dengan mengakses alamat web yang disediakan, pengguna layanan sudah bisa mengecek keberadaan suratnya tanpa harus mendatangi satu persatu instansi atau bidang untuk mencari keberadaan suratnya tersebut, hal ini dikarenakan prosedur dibuat semudah mungkin agar tidak memberatkan pengguna layanan, selain itu agar pelayanan menjadi lebih cepat". ("wawancara dilakukan pada tanggal 23 april 2021).

Hasil wawancara tersebut menunjukkan bahwa penyederhanaan pelayanan Program E-surat telah membuat pengurusan surat menjadi lebih efisien. Masyarakat tidak perlu lagi berhubungan dengan banyak instansi atau bidang lain berserta prosedurnya sangat sederhana, yaitu memenuhi persyaratan memasukkan surat, menunggu dan mengecek tracking surat tersebut dan menunggu hasil disposisinya.

\section{Kepuasan}




\section{JPASDEV}

Journal of Public Administration

and Sociology of Development

Aspek kepuasan dalam melihat efektivitas organisasi adalah sampai sejauhmana pembentukan organisasi dapat memberikan kepuasan tidak saja bagi internal organisasi baik pimpinan maupun staf, tetapi juga dapat memberikan kepuasan kepada masyarakat atau publik (pengguna layanan) sebagai wujud pertanggungjawaban dibentuknya organisasi tersebut, terlebih bagi organisasi yang bergerak dalam bidang pelayanan publik seperti Biro Umum.

Terkait dengan kepuasan Program E-surat di Biro Umum Sekretariat Daerah Provinsi Kalimantan Barat dalam memberikan pelayanan kepada pengguna layanan, Dwi Purwanto, A.Md selaku admin Program E-surat di TU Biro Umum menyatakan:

"menurut saya Biro Umum dalam memberikan pelayanan Program E-surat sudah berupaya untuk memberikan pelayanan terbaik kepada pengguna layanan dengan sangat ramah, sopan dan cepat. Namun demikian, harus diakuin bahwa masih ada beberapa kekurangan yang mungkin belum
Vol. 2, No. 2, Desember 2021

memuaskan pengguna layanan, misalnya saja ada beberapa staf yang lupa mengentri surat sehingga pada saat pengguna layanan datang untuk menanyakan keberadaan suratnya, surat susah dideteksi keberadaannya". (wawancara pada tanggal 22 april 2021).

Berdasarkan keterangan dari informan yang berasal dari Biro Umum Sekretariat Daerah Provinsi Kalimantan Barat menunjukkan bahwa dari segi kepuasaan, Biro Umum Sekretariat Daerah Provinsi Kalimantan Barat sudah memberikan pelayanan terbaik, dengan berbagai kekurangan yang ada. Kepuasan tersebut ditunjukkan dengan peningkatan kualitas pelayanan pengurusan surat kepada pihak pengguna layanan, yang dulunya memakan waktu lama kini menjadi lebih cepat. Meskipun diakui bahwa pelayanan yang diberikan masih belum maksimal dan dapat memuaskan publik, karena kurangnya dukungan sumber daya.

Efektivitas Program E-surat di Biro Umum ditinjau dari aspek kepuasan sebagaimana yang disebutkan diatas, 


\section{JPASDEV}

Journal of Public Administration

and Sociology of Development

dapat saja dijadikan tolak ukur melihat kualitas pelayanan yang dilaksanakan oleh suatu instansi, akan tetapi keberhasilan suatu instansi tidak sematamata dapat diukur dari pengakuan instansi tersebut, persepsi pihak luar (eksternal) organisasi juga perlu dijadikan bahan pertimbangan guna mengetahui sejauhmana masyarakat puas dengan Program E-surat dalam pengurusan surat. Terlebih pihak- pihak yang dilayani (pengguna layanan), yang merasakan secara langsung bagaimana pelayanan yang diberikan. Untuk mengetahui bagaimana tanggapan pihak yang dilayani, penulis melakukan wawancara dengan beberapa orang, yang pernah melakukan pengurusan surat.

Dalam wawancara yang dilakukan secara tidak langsung denganM. Saifudin selaku pengguna layanan pengurusan surat di Biro Umum adalah seorang ASN yang berasal dari Pemerintah Kabupaten Sambas memberikan keterangan yaitu:

"pada saat saya mengurus surat tembusan mutasi saya yang ditujukan untuk Bapak Gubernur
Vol. 2, No. 2, Desember 2021

masih terdapat beberapa hal yang menurut saya masih kurang optimal, yaitu pada saat saya ingin menanyakan keberadaan surat saya, petugas pelayanan atau admin di TU Biro Umum sedang melaksanakan Diklat sehingga izin tidak masuk ke kantor, dari informasi dan arahan admin, saya diminta untuk menghubungi admin lainnya namun beberapa kali saya menanyakan juga belum ada informasi jelas dimana keberadaan surat saya, sedangkan posisi saya berada di Kabupaten Sambas sangat jauh untuk datang menanyakan langsung, akhirnya saya memutuskan berangkat ke Pontianak untuk menanyakan langsung ke kantor Biro Umum terkait surat mutasi saya, setelah saya datang langsung baru saya menemukan tracking surat tersebut". (wawancara melalui via telepon atau whatsapp pada tanggal 6 juni 2021).

Berdasarkan hasil wawancara yang dilaksanakan dengan beberapa masyarakat tersebut menunjukkan bahwa masyarakat belum begitu puas dengan pelayanan yang diselenggarakan oleh Biro Umum, meskipun mereka sangat mendukung Program E-surat tetap dikembangkan karena cukup 


\section{JPASDEV}

Journal of Public Administration

and Sociology of Development

Vol. 2, No. 2, Desember 2021

memberikan kemudahan jika berjalan sesuai dengan tahapannya

dibandingkan dengan pengurusan surat bahkan lebih efisien jika dilihat dari yang dilakukan dengan mencatat secara sistem pencatatan surat masuk secara manual. Kurangnya kepuasan pihak pengguna layanan terhadap pelayanan yang diselenggarakan Biro Umum perlu direspon oleh Biro Umum untuk membenahi berbagai kekurangan sehingga dapat memberikan kepuasan kepada pihak pengguna layanan.

\section{SIMPULAN DAN REKOMENDASI}

\subsection{Simpulan}

Efektivitas Biro Umum dalam menjalankan Program E-surat di Sekretariat Daerah Provinsi Kalimantan Barat, meliputi adanya: a) Produksi yang terdiri dari pelayanan surat masuk, pelayanan informasi disposisi surat dan pelayanan penomoran surat sudah manual, namun belum optimal. Hal ini dibuktikan dengan masih adanya beberapa kendala seperti jaringan internet yang mengalami gangguan, pegawai atau admin yang masih mengalami human error, serta sarana dan prasarana yang masih terbatas; b) Efisiensi yang terdiri dari efisiensi waktu, efisiensi biaya pelayanan dan efisiensi prosedur pelayanan sudah lebih efisien bahkan saat ini baik dari pihak internal organisasi maupun eksternal organisasi menyatakan Program E-surat sudah cukup optimal karena pelayanan yang dirasakan lebih cepat dan efisien, namun tetap harus ditingkatkan; c) Kepuasan yang dirasakan pihak internal organisasi sudah cukup puas walaupun belum optimal, namun dari pihak eksternal organisasi merasa belum puas, hal ini dibuktikan dengan masih adanya pihak publik yang kesulitan dalam melacak keberadaan suratnya.

\subsection{Rekomendasi}




\section{JPASDEV}

Journal of Public Administration

and Sociology of Development

Vol. 2, No. 2, Desember 2021

Dalam meningkatkan efektivitas biro umum dalam menjalankan program E-surat di sekretariat daerah provinsi Kalimantan barat yaitu dengan beberapa cara sebagai berikut: 1) Mengubah pola pikir pegawai secara bertahap dengan meningkatkan sosialisasi terkait efektivitas Biro Umum dalam menjalankan program E-surat di Sekretariat Daerah Provinsi Kalimantan Barat serta meningkatkan motivasi tiap pegawai dengan cara membangun hubungan baik antar pegawai di lingkup Sekretariat Daerah Provinsi Kalimantan Barat; 2) Melibatkan seluruh OPD (organisasi perangkat daerah) yang ada di

\section{REFERENSI}

Moleong, J L. (2000). Metodologi Penelitian Kualitatif. Bandung: Remaja Rosdakarya Offset.

Noor, J. (2011). Metodologi Penelitian. Jakarta: Prenadamedia Group, h.33.

Sari, K. D. A, dan Wahyu, A. W. (2016). "Implementasi EGoverment System Dalam Upaya Peningkatan Clean and Good Goverment Di Indonesia," Jurnal Jeam volume XI, no. 1 (2012): hlm. 2 . lingkungan Kalimantan Barat untuk menggunakan aplikasi E-surat dalam pengurusan surat menyurat; 3) Disediakannya sarana dan prasarana yang baik seperti membuat fitur entri surat untuk akun seluruh OPD (organisasi perangkat daerah) sehingga OPD lain yang ingin mengirim surat ke lingkungan Sekretariat Daerah, cukup dengan melakukan entri diaplikasi saja tidak perlu mengirimkan surat fisiknya. Hal ini juga berkaitan dengan pandemi Covid-19 yang sedang terjadi saat ini, dimana untuk mengurangi interaksi langsung tiap pihak.

\section{ATURAN PEMERINTAH}

$\begin{array}{ccr}\text { Biro Umum } & \text { Sekretariat } & \text { Daerah } \\ \text { Provinsi } & \text { Kalimantan } & \text { Barat } \\ \text { Instruksi } & \text { Presiden Nomor } 3 \\ \text { Tahun 2003 tentang } & \text { Kebijakan } \\ \text { dan } & \text { Strategi } & \text { Nasional } \\ \text { Pengembangan } \text { e-government }\end{array}$

Peraturan Menteri Pendayagunaan Aparatur Negara dan Reformasi Birokrasi (Menpan RB) Nomor 6 Tahun 2011 tentang Pedoman

Umum Tata Naskah Dinas Elektronik (TNDE) 


\section{JPASDEV}

Journal of Public Administration and Sociology of Development

Vol. 2, No. 2, Desember 2021 